\title{
Writings Of Ismat Chughtai: A Document Analysis Through Symbolic Interaction Paradigm
}

\author{
Sabahat Raza \\ \& \\ Naila Usman Siddiqui \\ Department of Sociology \\ University of Karachi
}

\begin{abstract}
Ismat Chughtai is undoubtedly one of the biggest names in Urdu Literature. The following research paper intends to analyse the appearance of social issues such as informal social control over women in a patriarchal structure, portrayal of a female body in the advertisement, relationship pattern of men and women, notions of women as inferior being of society, in the selected writings of Ismat Chughtai, in relation to symbolic-interaction paradigm. The core idea of Symbolic-interaction is that social realities are based on the social experiences, cognition and perception of an individual. The social understanding of an individual varies from situation to situation and depends on his/her experiences. Ismat Chughtai experienced society in her own way, which is portrayed in her fictional works, "Dil Ki Dunya", a novel, "Khareed Lo", "Paisha", "Baykaar" and "Tera Haath", the short stories and a non-fictional essay, "Aurat" which are chosen for the analysis of above-mentioned social issues in relation with the theory. It is concluded that Ismat's writings are valuable, meaning full and relevant in as well in Sociology as in Psychology or Philosophy, in relation to Symbolic Interaction. Documents for analysis were chosen through Purposive sampling, the nature of research is inductive.
\end{abstract}

Keywords: Symbolic-Interaction Paradigm, Patriarchy, Women in Advertisement, Stereotyping, Relationship pattern, Informal Social Control

$$
\begin{aligned}
& \text { تلخيص }
\end{aligned}
$$

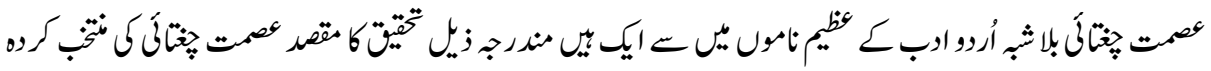

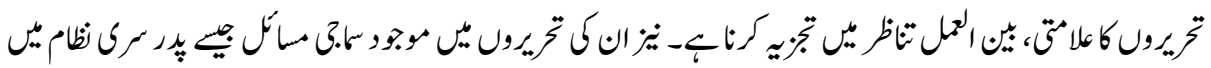

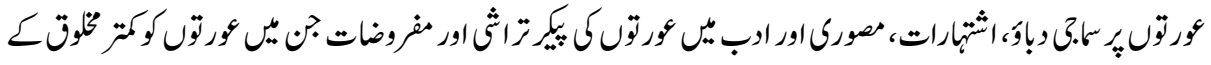

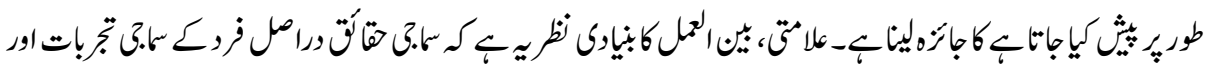

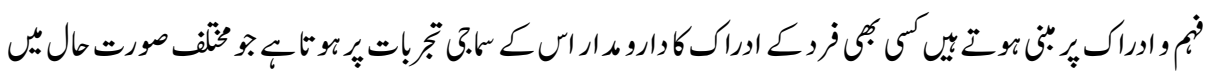

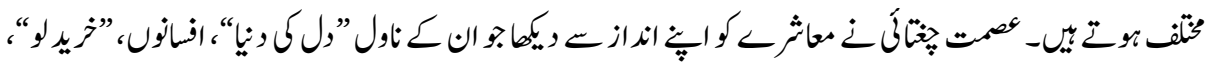




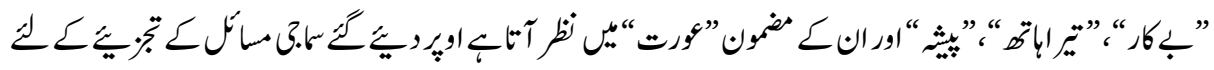

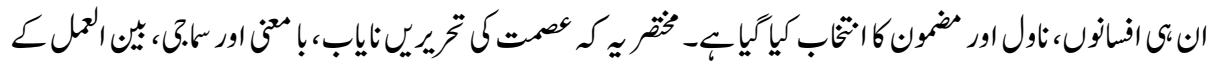

$$
\begin{aligned}
& \text { تحلق سعرانيات }
\end{aligned}
$$

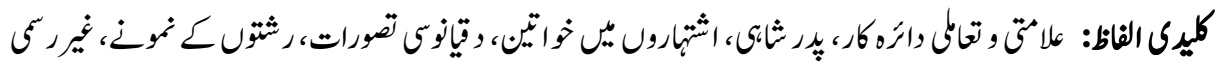

$$
\begin{aligned}
& \text { س.ك تلطا. }
\end{aligned}
$$

\section{Introduction}

"When a woman is widowed, her bangles are broken into pieces. But why when a man becomes a widower, his glasses and wrist watch are not broken?'(Farrukhi, 2015)

Ismat Chughtai was born on 21 August 1915 in a literate family of Badayun, India. The famous comic writer Mirza Azeem Baig Chughtai was her elder brother. She learned History and English from her brother (Abdul-Rehman, 2012). She wrote a number of beautiful short stories, novels, essays under the banner of Progressive Writer's Movement of India. Progressive Writer's Movement of India opposed the British rule in India and took an active part in pushing the independence movement. Saadat Hasan Manto, Krishin chandar, Rajinder Singh Baidi and Khwaja Ahmed Abbas were her contemporaries (Abdul-Rehman, 2012). It is truly acknowledged that in a patriarchal society, among so many men, she made everyone to recognize her. She penned down a number of social issues in her writings but her main focus is woman. She presented oppressed women in her fictional and non-fictional work. Her stories mainly revolve around the problems women were facing in her time. "In most of her short stories she points a finger at society for unjust treatment of women." (Parekh, 2015).She resisted patriarchal structure and she loudly opposed the male domination.

This paper is an attempt to explore the issues and problems of women of British colonial India in Ismat's writing, through symbolic-interaction perspective of sociology, mainly influenced by pragmatism. Pragmatists believes that reality does not exist, it is created by people, secondly people believes on what seems beneficial to them, third, people describe the worldly objects as what they perceives. "These three points are critical for symbolicinteraction: a focus on the interaction between the actor and the world, a view of the both the actor and the world as dynamic processes and not static structures and the great importance attributed to the actor's ability to interpret the social world." (Ritzer, 2011). Human beings, unlike other species are blessed with the capacity of thought. Social 
interaction gives birth to symbols and gestures and human beings perceive these symbols and gesture according to their situation and then gradually this leads towards group formation or the foundation of the society. For Example: Women perceived their selves deceitful and oppressed so that they raised voice against male domination. The feminist movement of early $20^{\text {th }}$ century gathered all the women around the globe and they form a group, which we call feminist group. The symbolic-interaction considered socialization as the most important part of the human life. They believe that socialization shape up the thinking process of a human being. As a student of sociology and society when Ismat Chughtai is read or understood it was evident in her writing that she discuss the socialization of a girl child in a patriarchal society in her time under the notion that reality is nothing but a social construction in time and space.

Since the suggested study is qualitative, so that it will be heading towards hypothesis generating research. Non-probability purposive sampling technique is used to collect data. As the proposed research is secondary in nature so the secondary sources will be used for data collection. Data will collect from the historical documents, books, newspapers, and websites.

The English translations of Ismat Chughtai's writings which are chosen for the study are not available. A book titled The Quilt and Other Stories was published in 1994 by Oxford University Press; it included the English translation of few of Ismat's stories translated by Tahira Naqvi. This book is now out of print. Her novel Dil ki Dunya was also once translated as "The Heart Breaks Free", it is also out of print. Therefore there was no choice but to get the text translated. The text included in the study is translated by Mrs. Sara Kazmi, who is a Senior Research Fellow at Area Study Centre for Europe in University of Karachi. Mrs. Kazmi has done her Masters in both English Literature and Linguistic. She is currently doing her M.Phil research in English Literature.

\section{Literature Review}

A number of researches have been done on the fictional and non-fictional works of women writers around the globe.

Crosier (2010), studies the writings of Emily Bronte from the viewpoint of self-reflective learning theory. Crosier (2010) believes that Emily Bronte's environment influenced her creative writing. The essays written by Emily in her young age, her father's letters to her aunt, Emily's elder sister charlotte's letters, Emily's birthday papers and her poetry proves that Emily's everyday experiences greatly influenced her writings. The sorrow of her mother's death followed by the deaths of her two elder sisters reflects in her writings Crosier (2010). 
Mazzucchelli, (2009) studies Virginia woolf's "To the Lighthouse" and debates on female anger. Mazzucchelli, (2009) observes that Woolf's novel "To The Lighthouse" shows three angers, first the anger of Virginia Woolf towards patriarchal structure, secondly Mr. Ramsay's anger towards her wife for not expressing her love and third the anger of Mrs. Ramsay towards her husband.

Kaivola and Sheriden (n.d.) sociologically analyzed Virginia Woolf's novel "To The Lighthouse". Kaivola and Sheriden (n.d.) overviews the socially construct gender roles Woolf presented in the abovementioned novel. Woolf criticized the role of a woman as a housewife. A woman is expected to fulfil her domestic duties like, cooking, cleaning, child-rearing etc and then she is expected to express her love to her husband. Late at night when husband reads a book wife was busy in knitting. Woolf argues that these activities suppress the intellect of a woman. It is necessary to understand that the novel was written in early $20^{\text {th }}$ century where men and women have their separate spheres. Kaivola and Sheriden (n.d.) argues that sex is classified on the basis of biology but as far as gender concerned it focuses on the inequality between the two sexes that is man and woman which is the central focus of the writings of Virginia Woolf especially the novel, "To the Lighthouse".

The women writers of India are always been a source of attraction for the researchers. Elizabeth Jackson (2010) supervised a comparative study of contemporary women writers of India in relation with feminism. Jackson (2010) chose four popular women writers that are Anita Desai, Kamala Markandaya, Shashi Deshpande and Nayantara Sehgal. Jackson pick up five variables that is Women, Cultural Identity and Social Class, Marriage and Sexuality, Motherhood and women's role in maintaining patriarchy. Jackson (2010) reviews the writings of abovementioned writers in the light of these variables as all four writers talked over the problems women are facing even in modern age.

Chaudhry (2013) analyzed the writings of renowned Pakistani female writers, Bapsisidhwa and Qaisra Shahraz. Both writers wrote in English. Chaudhry also analyzed a novel written by a contemporary Urdu fiction writer Umaira Ahmed. In her thesis Chaudhary proves that the abovementioned writers highlight the serious issue of the humiliation of female body. A female body is defined as a sex symbol in a patriarchal structure. Chaudhary studies that all three writers defies the wrong interpretation of religion and culture by men. The exploitation of female body is strongly condemned by abovementioned writers. The voice of female authors against patriarchy is a great contribution towards the freedom of women (Chaudhary, 2013). 
Ahmed (2009). Chose Bapsi Sidhwa, Zulfikhar Ghose, Qaisra Sharaz, Mohsin Hamid and Nadeem Aslam to analyze the presentation of female figures in the writings of abovementioned writers. Ahmed observes that the female characters are presented by these writers as oppressed, mentally dissatisfied and dependant. The transformation of these dependant and oppressed women into an independent and strong human being is observed in prior writings (Ahmed, 2009).

Ismat Chughtai has been a central focus of researchers, due to her sharp feminist voice which she raised in her fiction and non-fiction, due to social paradigms she discussed in her stories and essays, due to rejecting patriarchal structure loudly. A number of researches have done on Ismat Chughtai and her work.

Tanvi Khanna (2014), analyzed Lihaaaf (The Quilt), the famous and the most controversial story by Ismat Chughtai. Lihaaf, was published in 1941 in Adb-e-latif, a famous literary journal. Khanna wrote that in Lihaaf the truthof zenana (a private sphere in a Muslim household where women were kept and it had no connection with the outer world) was exposed off by Ismat Chughtai. Khanna wrote that: "Lihaaf sexualizes the zenana and challenges the image of a woman subservient to the dictates of patriarchy". Khanna explores that Ismat Chughtai was the advocate of sexual liberation. She believed that sexual liberation is a source of self -actualization and self -realization. Khanna examine lihaaf as a rebellious voice of a bold woman who, through this story challenges the patriarchal structure. Khanna wrote: "By sexualizing the zenana, Chughtai gives a blow to patriarchal ideology that zenana is the sanctum sanctorum of the house and is, therefore, free from the invasion of any form of sexuality."

Shanthi Pradeeep reviews the problems Northern Indian women faced after marriage. She also focuses on the short stories which highlights the issues of subaltern. Pradeep explores through selective short stories of Ismat Chughtai that Marriage is very necessary in this society, no woman can live alone and only decent marriages are acceptable. In decent marriages are not accepted in the society. It is also analysed that men wants control over women's body. Pradeep wrote:"Every woman is expected to live according to the wish of her husband and she has to sacrifice everything after marriage". Pradeep reviews the characters of Lajo, Gainda, Bashariya, Kubra and Samina. Gainda and Bashariya were married in their childhood and expected to become decent women as they were married. Kubra was never married because she was poor and her parents had nothing to give her as dowry. Samina married to a Hindu and bears a curse of Indecent Marriage and Lajo a low caste woman was married to a noble man who from next day of his marriage pointed out her weaknesses and wanted her to be a noble woman. Pradeep also explores that sub alternity is another issue raised in the stories of Ismat Chugtai. In the story "Tiny's Granny" or "Nanhi ki Naani" nobody advocates Tiny and Granny as 
they were poor and there was no male relative to protect them. As it is, Pradeep reviews the character of Lajo, who when married to a nobleman and then divorced. She was happy when living alone, she had no wish to marry Miirza but who asked for her wish? Pradeep (2013) noticed that in the "The Wedding Suit", all three Bi Amma, Kubra and Hamida are subalterns. They had no man in the family to raise voice for them, even when a guest named Rahat came to live with them and played some pranks with the young girl nobody said anything and that he knew that he is living in house where there is no man to question him?

Hafiza Nilofer Khan (2008), reviewed a treatment of a wife's body in accordance with the fictional and autobiographical writings of three sun-continent writers that is Ismat Chughtai, Selina Hossein and Tehmina Durrani. Social issues like child marriage, killing in the name of honour, dowry system, lack of decision making in married women, marital rape depicts in the writings of aforementioned writers (Khan, 2008).

\section{Symbolic-Interaction Perspective}

Sociology is based on three paradigms, Structural-Functional Paradigm, Social-Conflict Paradigm and Symbolic-Interaction Paradigm, contributed by the Chicago school of thought. The first two perspectives, Structural-Functional and Social-Conflict have macro level alignment. Structural-Functional perspective sees society as a body in which all parts works together to sustain a social system. It is basically a substructure that prospects the integration of society, interdependency of its social institutions and their functions. Social-Conflict paradigm, on the other hand, focuses on the division of a society. Based on the philosophical work of Marx, it overviews the prevailing class systems as social inequality which benefits some and detriment for others. This social inequality brings change in a social system. Now Symbolic-Interaction perspective in Sociology has a micro level inclination, it over view society from the standpoint of an individual. How an individual experiences a society. Based on the work of Max Weber, Symbolic-Interaction paradigm deals with the interaction of human beings, their communication, their experiences, their perceptions and variation in a human behaviour from situation to situation, in symbols and gestures etc (Macionis, 1989).

\section{Woman in Advertisements, Art and Literature}

An Analysis of Chughtai's Short Stories, "Khareed Lo", "Tera Hath" and "Paisha". "Khareed Lo", is a short story written by Ismat Chughtai. Set in western society, the story is about the advertisements which portrayed women as subservient. Cathy, a young girl aged 15 years hardly, who is a neighbour of narrator's land lady, is a fashion freak. Her 
mother works in a factory and she herself earn some money by babysitting and works as a housemaid in neighbouring houses after her school. The land lady does not like her as she is so hyperactive. Cathy's only attraction in land lady's home is a full length mirror in front of which she put on makeup which she buys from the wholesale market. One day when narrator called Cathy on the road she ignored and went to tube station, there the narrator came to know that she was not Cathy, a number of girls just like Cathy were going here and there. Same orange mules, orange miniskirts, white blouses.

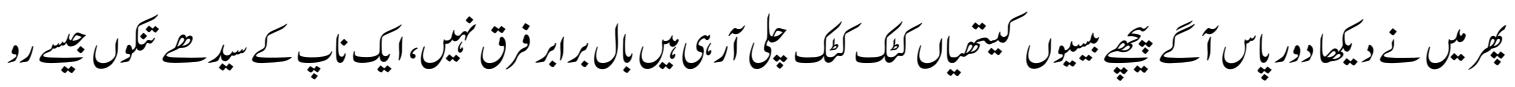

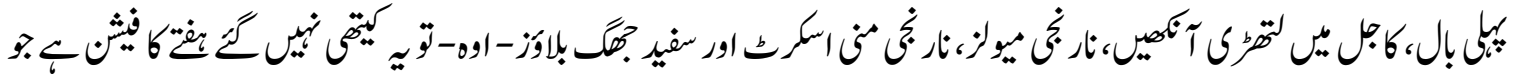

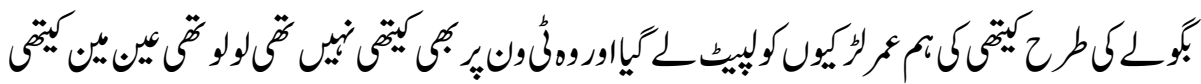

(Abdur-Rehman, 2012)

“Then I viewed, far, nearby and everywhere, hundreds of 'Cathies' came tramping, identical in size, hairs like bamboo sticks... eyes brim-full with kajal, as though crimson mules ..., crimson miniskirts and white blouses. Oh! This wasn't Cathy; it was more of a weekly fashion show which had engulfed same-age girls like a powerful flame!"

The narrator came to know that it was Jina Loollo Brigida, the famous actress of her time, who was copied by every girl. Here the narrator sarcastically pointed out that even the civilized nations of the civilized world are in the trap of advertisements.

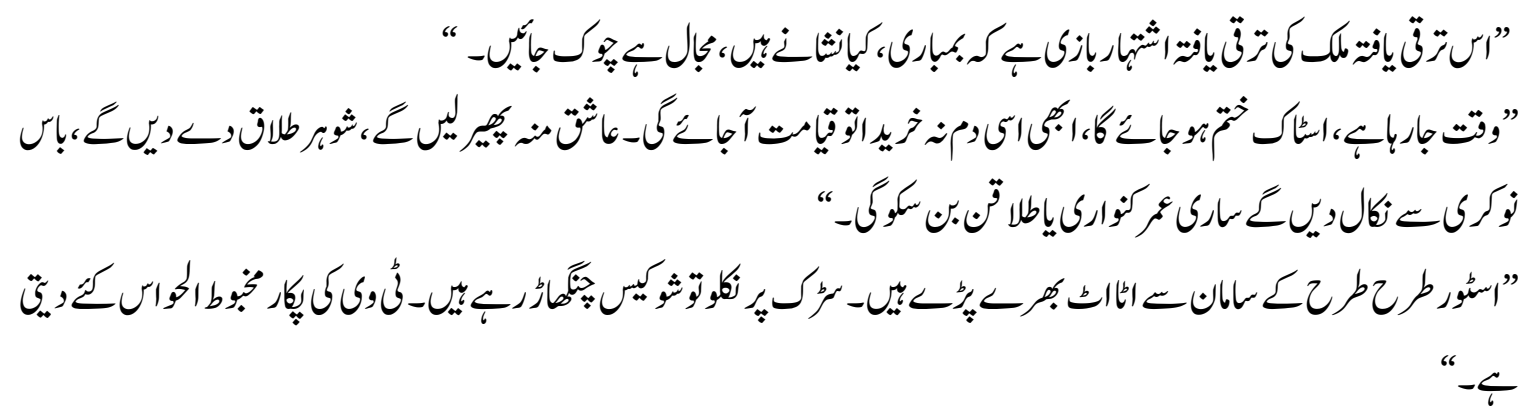

(Abdur-Rehman, 2012)

"In this developed country, is this a rage of marketing gimmicks or aerial blitz? Never does it go amiss! Time is running short, the stock will finish. You shall be doomed to hell lest you buy now. Lovers would abandon you, husbands will divorce, bosses shall sack from job, and you will be doomed to lifelong spinsterhood or the miseries of 
separation. Stores are replete with miscellaneous commodities. If you go out on the roads, showcases glare at you. The sound of TV is deafening."

Gradually Ismat define the social dilemma of advertisements which compel common people to buy the products which are advertised. Here she connects the theme of the story with feminist perspective when she says:

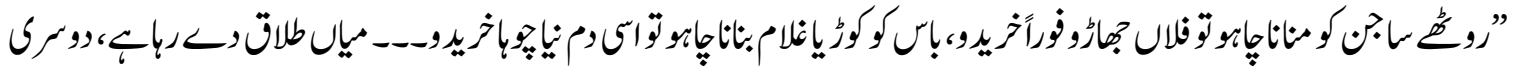

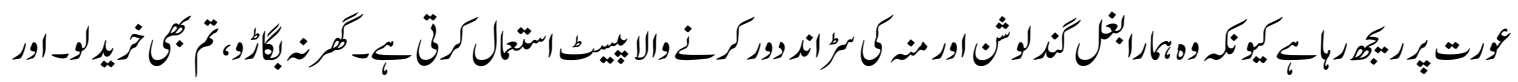

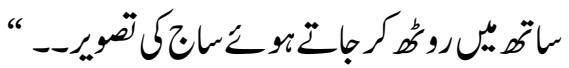

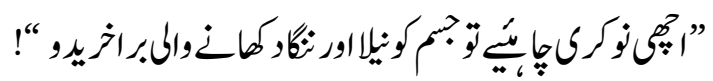

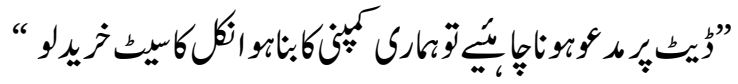

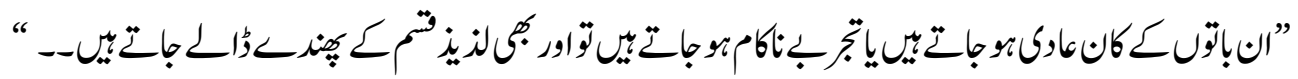

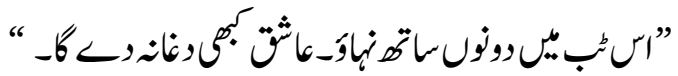

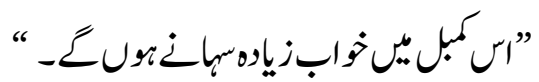

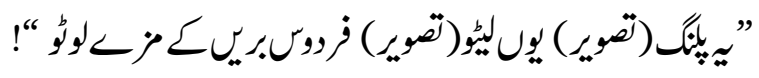

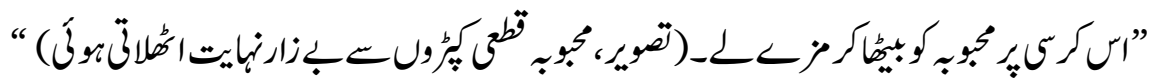

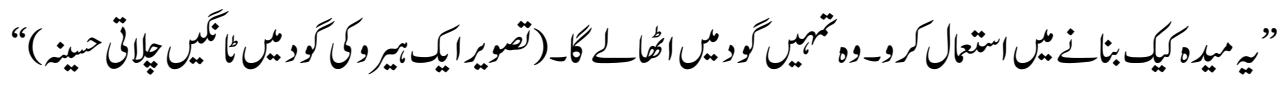

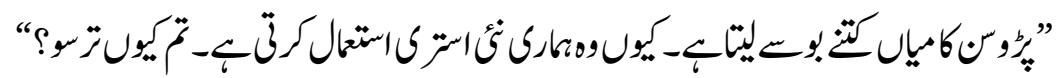

(Abdur-Rehman, 2012)

"In order to console a disappointed beloved, buy a certain variety of broom immediately, to turn your boss into general factotum, buy a new mouse on the spur of the moment...the husband is about to divorce, infatuated with another woman, only because she uses our underarms cleansing lotion and paste to remove oral malodour. Do not destroy your home, you should buy as well. And show cases the picture of the disenchanted beloved parting ways.

If you need a good job, buy a bra that shows the body blue and naked.

If you are in for a date, get hold of our company's nickel made set.

If ears get used to such statements, or experiences fail, new, attractive baits are employed.

Bathe in this tub together. Lover will never betray.

This blanket will promise sweeter dreams. 
Lying on his bed (followed by the picture of the bed), in this manner (tagged by a picture again), will earn you heavenly pleasures.

Have your girlfriend sit on this chair and enjoy. (A picture showing a provocative girlfriend tired of any complete attire).

This flour is used to prepare cake. Try it once and he shall take you in his arms. (Picture shows a girl with protruding legs in the arms of a hero).

The neighbouring woman's husband kisses her several times for she uses our iron. Why should you envy? "

It seems that it is an ultimate goal of a woman to make men around her happy; women through advertisement are made to believe that they are incomplete or unsuccessful without men, her lover, her boss, her husband etc. A fear of social insecurity revolves around women. They are incomplete without men. They either keep their men happy or they will lose them.

In all these advertisements women are symbolized as a body, an inferior, at the mercy of her husband, lover or boss. She has to expose her body to acquire a good job, she has to make her husband happy, if she will not iron his dress properly he will not kiss her, if she will not make a good cake she will not be loved anymore. It seems that the only thing in a woman's life is her male counterpart. His kiss, hug and love are everything for her and she is ready to do anything to acquire this kiss, hug and love.

At the end the said story the narrator found Cathy at Piccadilly Street, London, where she was sitting with a group of young people, at peace, as if she has found the truth of men women relationship.

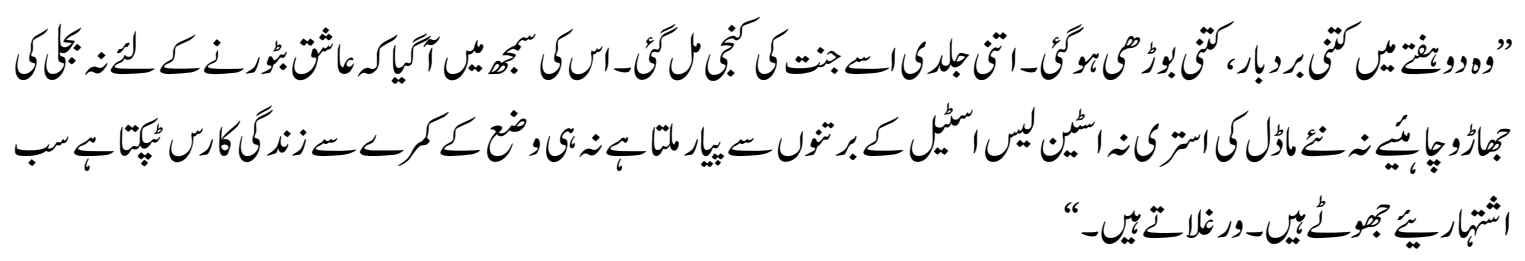

(Abdur-Rehman, 2012)

"How wise and seasoned she got in just about two weeks. She earned the key to heavens. She realized that in order to own a lover, neither electricity, nor broom will work, nor a new model of iron or stainless steel utensils will earn her love, nor does a newly furnished room oozes with the juice of life. All advertisers are liars. Only sweettalk." 
Even when she concludes the story she wrote:

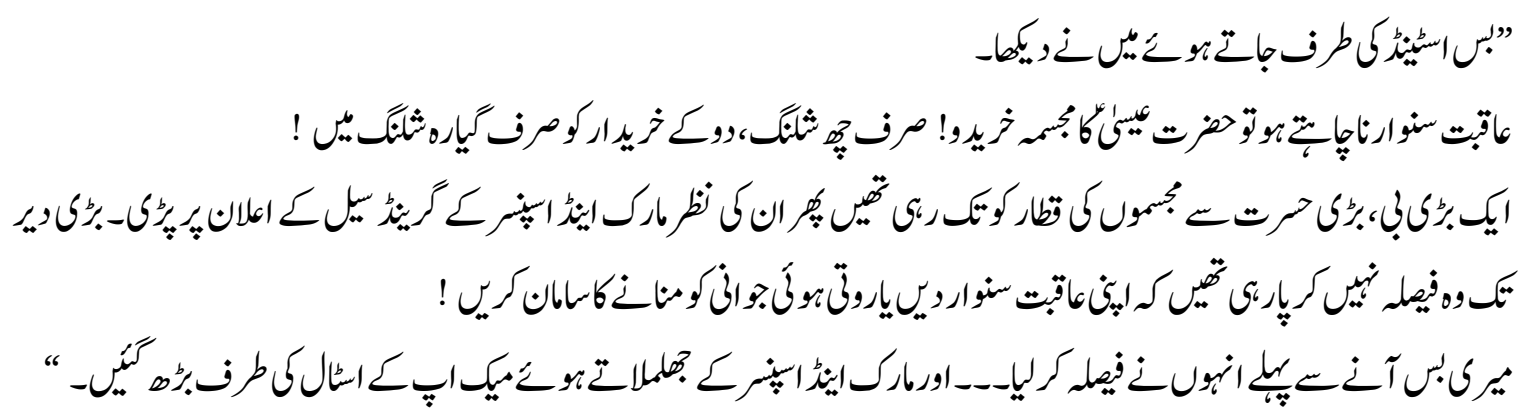

(Abdur-Rehman, 2012)

"Going towards the bus-stand, I (the narrator) notice.

If you want to better your hereafter, purchase the statue of Jesus Christ in just 6 shillings. One who buys two, will get it in only 11 shillings. An old woman eyed the array of statues with dismay. Suddenly she caught the glimpse of Mark and Spenser's Grand Sale. For long she remained indecisive as to whether she should better her hereafter or to resort to making up for her forlorn youth.

Before my bus came, she made her mind... and headed towards the glitzy make-up stall at Marks and Spencer."

In her short story, "Tera Hath" or "Your Hand" Ismat, at one place presented the traditional image of women presented in the popular literature of her time. She sarcastically discussed the novels of Mills and Boon and Barbara Cortland. She wrote:

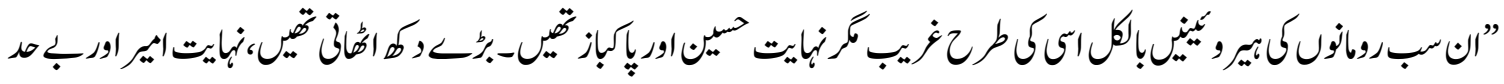

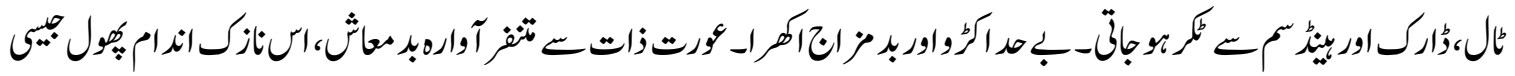

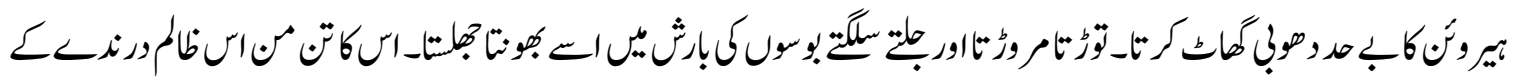

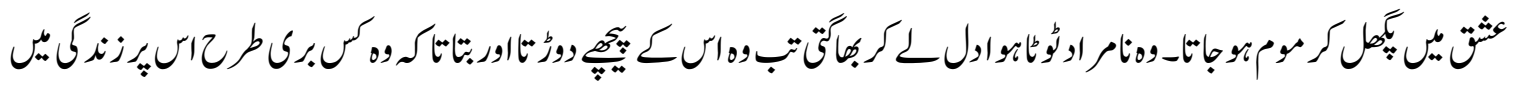

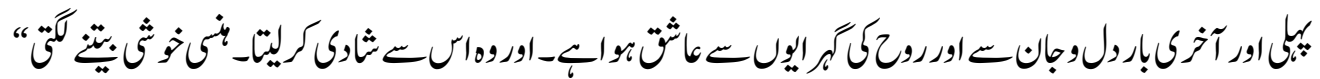

(Chughtai, n.d.)

"All heroines figuring in these romances were poor like her, but very beautiful and chaste. They bore many pains. They bump into a very tall, dark and handsome (gallant). Extremely angry and impolite stubborn, he is disillusioned with stray and immoral women. This heroine clad in a worn out outfit twisting and turning around in a cascade of hot and fiery kisses by him. Her entire being melts in love for this 
tyrannical lover. She runs with heartbroken yet he chases her and proclaims that he has fallen in love with her from the core of his heart for the first and last time. And he marries her, living happily ever after."

Here two things are clear, one that women are always and almost in every society socialized as a fragile object. A pretty, delicate woman is always loveable. Women's body is everything. Her pretty face, delicate walk, soft voice makes her heroine in popular literature and majority of readers loves this type of heroine that's why it is observed that progressive literature does not make an effect on larger population as the rebel, independent and courageous heroines were not acceptable and even today the presentation of an independent, powerful and intellectual woman as main lead in literature / dramas and movies are not liked by majority.

Secondly it's also presents an image of a woman who sacrifice herself to please her lover. A man's love is the main objective of a woman's life.

In her another short story, "Paisha" or "Profession" Chughtai discussed prostitution as a profession in which a female body is a central point. Story revolves around the narrator who teaches in a girl's school and lives in a building where her neighbour is a prostitute with her young daughter who is trained to trap customers by using her body. Firstly the narrator avoids the prostitute but curious she is, went to her home one day, where she found out that her home is so luxurious. Chughtai wrote:

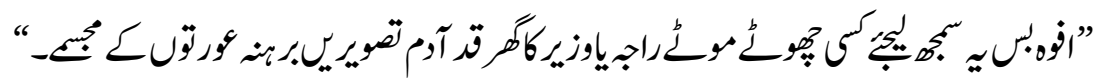

(Chughtai, 2013)

"Phew! Just imagine that the house of an ordinary minister or a Raja, with life-size portraits and statues of naked women."

She further wrote:

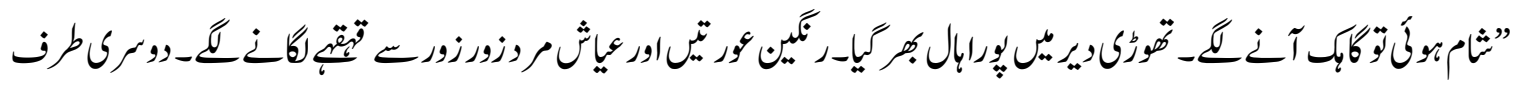

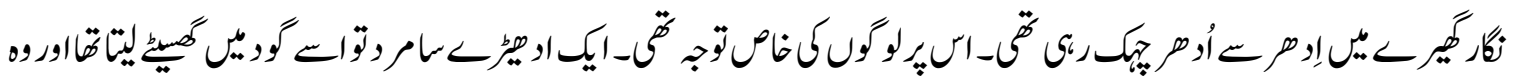

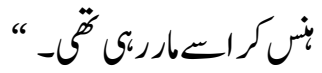

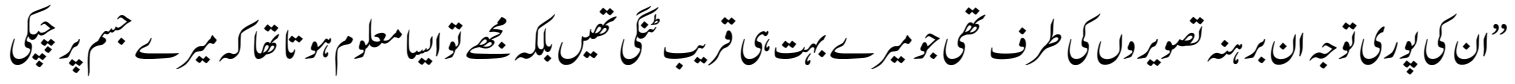

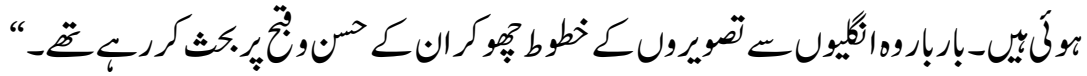

(Chughtai, 2013) 
"As evening fell, customers started pouring in. After some time the hall was full, colourful women and lecherous men, breaking into laughter. On the other hand, Nigar was chirping in this gathering here and there. A middle-aged man would push her into her lap and she would laugh back hitting him.

Their total attention was fixed on the naked pictures, hanging close to me. Rather it felt those were fixed on my body. They were touching the silhouettes of the pictures time and again and discussing the beautiful and the ugly therein."

Here we see that a female's body is seen as a source of satisfaction. For a man she is a sex symbol. Chughtai wrote at one point:

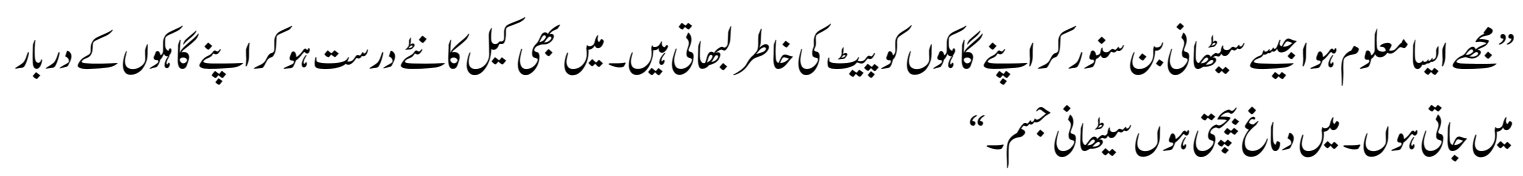

(Chughtai, 2013)

"I felt as though donning the garb of a rich landlady, she amused her customers out of hunger. After putting nails and forks in order, I also go into the court of my clients. I sell out brain, the landlady sells her body."

A female body is presented in the various forms of art and men discuss each and every part of her nude body and believe themselves as progressive, though by doing this most of the time they satisfy their lust. Chughtai criticized the Western society for it dual standards. Chughtai wrote:

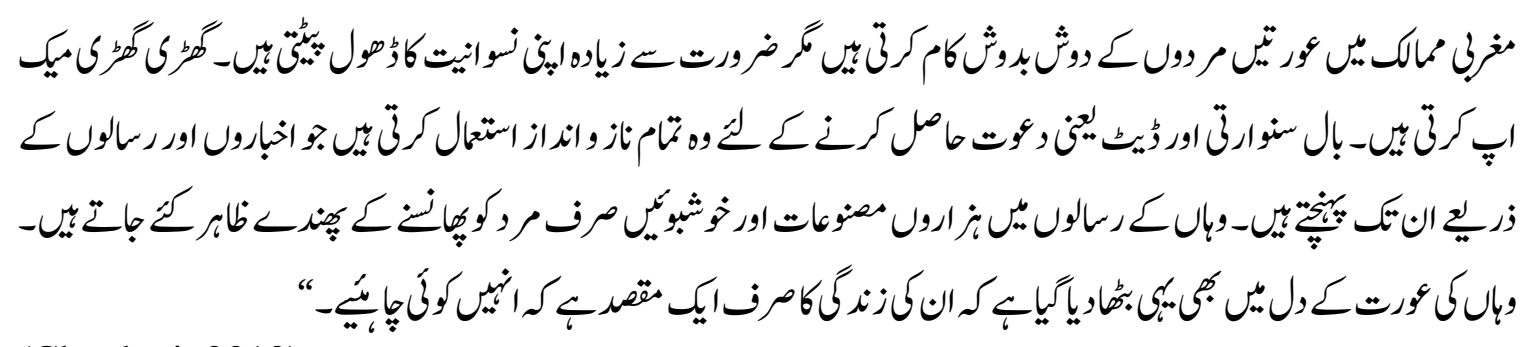

(Chughtai, 2013)

"In Western countries, women work along with men but she needlessly voices her feminism. Keeps doing make-up, styles her hair, and in order to hook a date, employs all those inviting gestures which reach her through magazines and newspapers. Their magazines and newspapers show thousands of products and perfumes only to ensnare men. The women over there have been trained into thinking that their only purpose is to hook someone." 


\section{Informal Social Control over Women: A Study of Chughtai"s Novel, "Dil Ki Dunya" and a Short Story, "BAYKAAR"}

In Ismat's novel "dilkidunya" or "The Heart Breaks Free" she pointed out the informal social control over women through socialization and stereotyping. Dil ki Dunya revolves around a girl Qudsia Bano or Qudsia Khala, who got married to her first cousin at the age of 15. After six months of her marriage her husband went to London and married again to a British lady. He never returned to his first wife Qudsia Bano, nor did he call her, that made Qudsia very frustrated and a talk of the whole family. The novel is written in the background of British Indian society, where the behaviour patterns of women were immensely controlled. A female child was socialized in oppressive manner. She was told every now and then how to move, how to sit, how to talk etc. In "Dil ki Dunya" the narrator says that she was scolded by her mother. In a humorous tone she wrote:

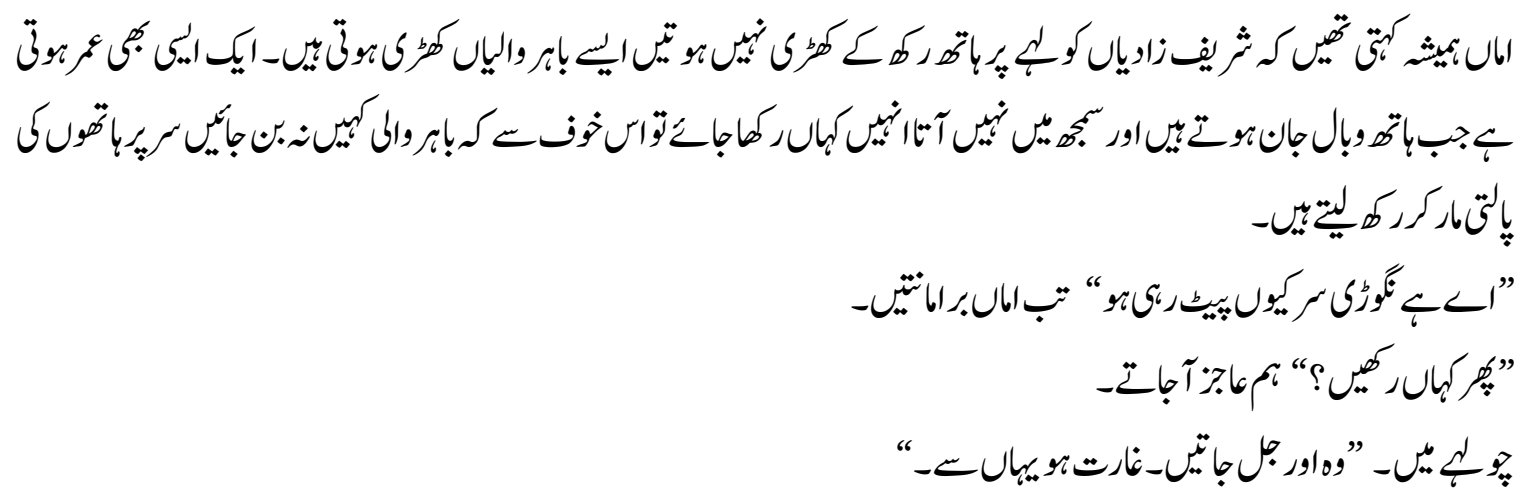

(Chughtai, 2013)

"Mother would always say that innocent girls would never stand up, keeping hands over their hips, the outcaste women stood like that. When hands and hair are lifeblood, one does not understand where to keep them lest we are termed as 'outcaste women'. So I would cross my hands on top of the head.

"O you foolish, why are you beating your head"? Mother would be displeased

"Where else should I keep my hands?"

, I would say helplessly.

"On the stove", She would retort, "go to hell”.

The above-mentioned dialogue gives a glimpse of the control a girl had to face, even her thoughts are controlled by patriarchy. When Qudsia Bano's husband did not contact her for 10 years, she became hysteric. She was not allowed to wear makeup and ornaments and good clothes, she had no right to live happily, she was a rejected woman, had to live in guilt. When she spends her life in this expected manner she was praised but at one point she got bored of her life. She was young and beautiful. She was attracted towards 
her brother-in-law, Shabbir Hasan, who regularly came to her house, used to recite "naats" for her. She started wearing makeup, decorative objects and fine colourful clothes. She starts smiling and laughing swiftly. This was a shock for everyone especially her mother.

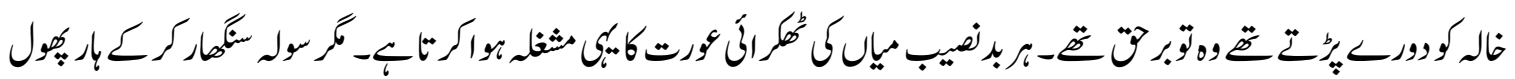

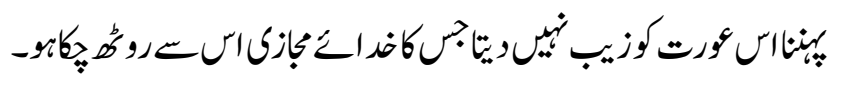

(Chughtai, 2013)

"Khala used to have fits, which was her legitimate share. Every abandoned woman at the hands of an unfortunate husband has the same fate. But beautifying herself, wearing jewellery does not befit a woman whose demigod (husband) had shunned her."

A woman whose husband was away is supposed to live like a widow. She had no rights to wear jewellery and makeup and fine clothes. This was the tragedy a woman faced in patriarchal society of sub-continent at that time (though these traditions still prevail in Indo-Pak). A woman had to marry, a single woman was not accepted by the society and those who are living with their husbands even oppressed were noble and those who were rejected by their husbands were supposed to sacrifice their each and every will, their smiles, their youth, their desires in the name of those husbands who were living a peaceful life with some other women.

QudsiaBano of "Dil Ki Dunya" or "The Heart Breaks Free" lived according to standard pattern of society for 10 years but after that she defied these rules and came out as a rebel and she cursed her husband start complaining to Allah:

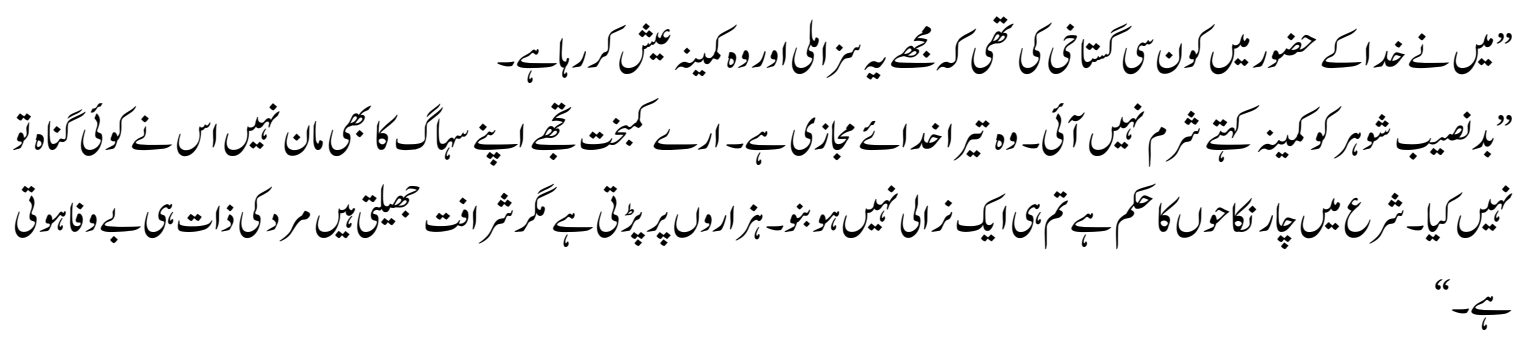

(Chughtai, 2013)

"What blasphemy did I carry out that I received this punishment whereas the rascal is enjoying. Shame on you, who calls her husband a 'rascal'. He is your demigod. Foolish you, who does not have any regard for her spouse. He did no wrong. Shariyat has allowed him the right to four wives. This befalls thousands of women. Are you out of this world, lady? But they bear with dignity, after all man is fickle and footloose." 
At this point it is observed that women were socially controlled and socialized by socially constructed beliefs, which were considered as a reality, a woman must obey the rules set by the society for her, as she has no free-will. But unlike other women Qudsia Bano denied these standard patterns and came out as a path breaker.

In her short story, "Baykaar" Ismat presents a very serious issue which is the hurdle a working woman face within and outside the family. This story revolves around a married couple Baqar Mian and Hajira Bi. Baqar Mian who was a government employee was fired from his job. Due to his non-serious attitude he never tried to acquire permanency. The family suffers due to unemployment. Hajira Bi's all jewellery was sold to solve the financial issues of the family. Hajira $\mathrm{Bi}$ had acquired matric certificate from Punjab which was a hallmark at that time. When a neighbour suggested to Hajira Bi to apply in a school for job the whole family opposed her. Bi Amma, the mother-in-law even cursed the forefathers of the neighbour. When Baqar Mian was told about this he said:

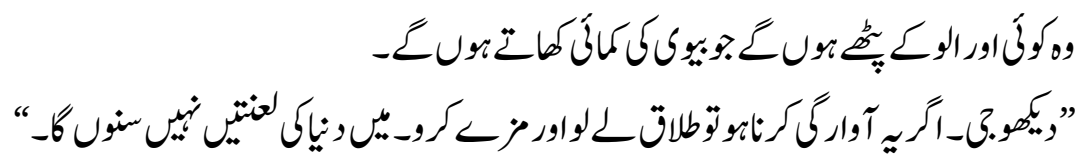

(Abdur-Rehman, 2012)

"Those are some other bastards who feed on their wives' income. Look here, if you want to indulge in this wickedness, get divorced and bask in pleasures. I would not listen to the curses of this world."

These dialogues articulate the informal social control over woman. How a woman whose husband is jobless, children are starving, is not allowed to go out to do something for her family, though she is skilful. How she is opposed when she tries to give financial support to her family, because it hurts the ego of her husband.

In her story, "Tera Haath", all three women, ammi, Khalaamma and Ghazala are portrayed as women whose all actions and behaviour patterns are controlled. Again it is observed that the walking style of girls was main concern. Everyone likes the delicate walk of girls; girls who walked fast were not liked by anyone. Here also Ammi is telling Ghazala that girls must walk with delicacy, not like animals.

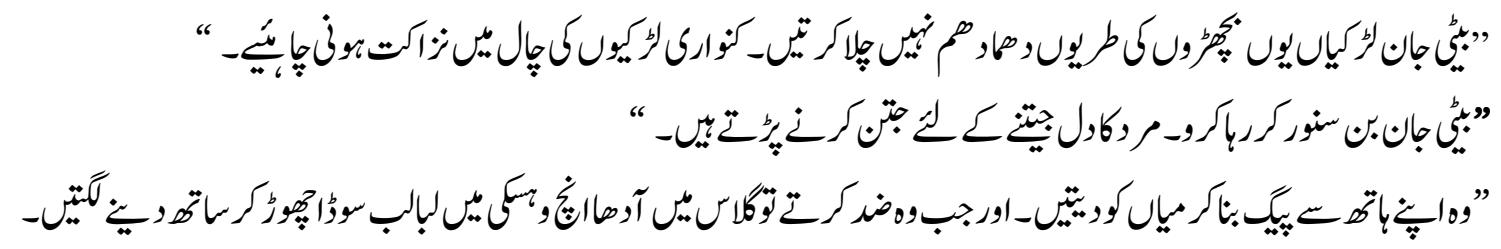


(Chughtai, 2013)

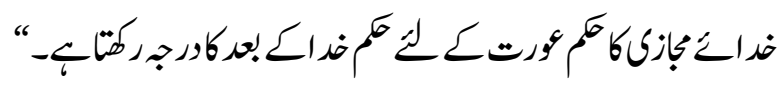

"Darling daughter, girls do not walk like dangling cows. The gait of unmarried women must be delicate."

"Darling daughter, keep you spick and span. One has to labour in order to win man's heart."

She would prepare hubby's bag with her own hands. When he would insist, she would leave her a glass of half an inch of whiskey with soda to take along. The command of a 'demigod' was only second to God's commandment for a woman."

This is an example of place and control over women. A woman has to wear jewellery and makeup and decorate herself to attract her husband. Secondly, it seems that at Ismat Chughtai's time women were socialized in a manner that they perceived themselves as subordinate. The above-mentioned dialogue that, "a husband's command is next to God's command" is showing the brutality of patriarchal structure. A woman's will was nothing; if her husband's wanted her to drink she had to do it, whether she liked it or not, in order to made him happy. This was the behaviour which Ismat loudly opposed and talked over again and again. She perceived the women of her time as a prisoner of century's old system and it seems that she portrayed her in her writings in order to provoke them.

\section{Stereotypes about Women: An Examination of Chughtai's "Aurat", a non-fictional essay and "BAYKAAR", a Short Story}

In her non-fictional essay, "woman" or "Aurat", IsmatChughtai presented some stereotypes related to womankind. She wrote:

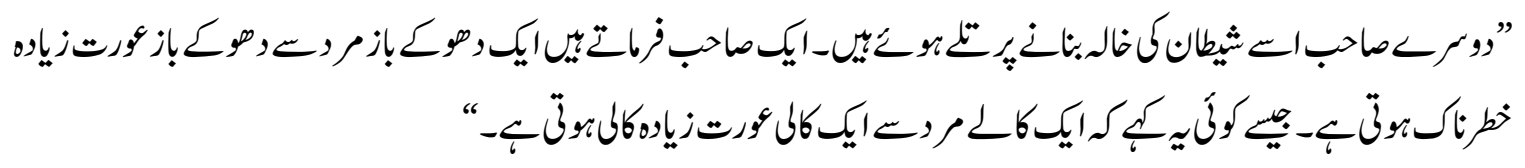

(Chughtai, 2013)

"Someone says, 'A woman is a devil's aunt'. Another man said' 'A treacherous woman is more dangerous than a treacherous man'.

These expressions are supposed to be real even women themselves believes it as a truth. Ismat wrote:

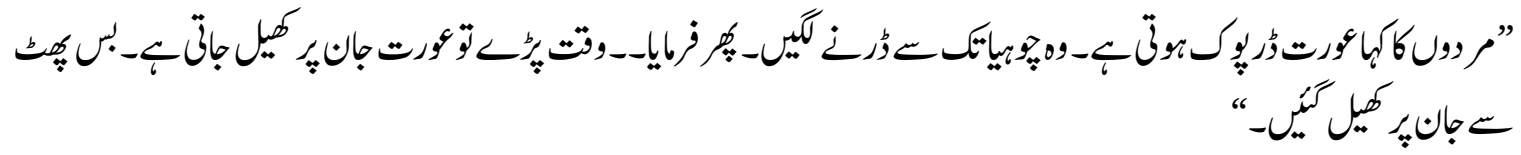

(Chughtai, 2013) 
"Men decreed that a woman is cowardly, and she started fearing even a mouse. Then they stated, a woman would not flinch from laying down her life, and she just instantly laid down her life!"

In every society patriarchal structure does not accept woman as equal to man and oppress her intellect through strange quotations which are constructed by people. Everyone start believing these build-up thoughts as actual and then society start practicing these socially constructed opinions. In patriarchal social structure a woman is socially controlled through these sayings sometimes.

(Chughtai, 2013)

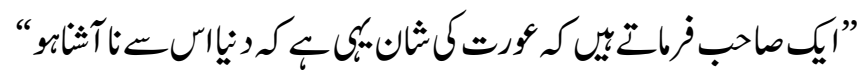

"A gentleman states that a woman's greatness lies in her alienation from the world."

Who said this? Why a woman can't popularizes herself. A patriarchal society expects that a woman must keep herself in the walls of a house.

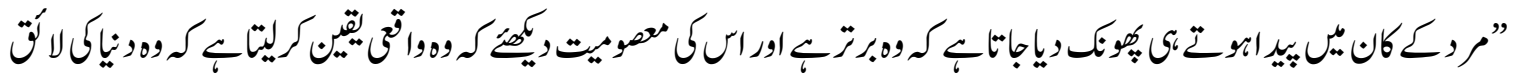

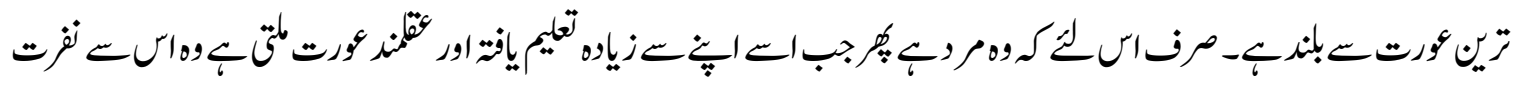

$$
\begin{aligned}
& \text { “- }
\end{aligned}
$$

(Chughtai, 2013)

"It is infused in a man's ears that he is above all and lo and behold, he is credulous enough to believe that he is above even the most seasoned lady of the world. Only because he is a man, whenever he encounters a woman more educated and wiser than him, he starts hating her."

How could it possible? How could a peon, cook, butcher, a clerk and a gardener be superior to Verginia Woolf, Simone De Bouvaire, Qurat-ul-ainHaider, Margret Thatcher and Ismat Chughtai and many other intellectual women of the world. This is what symbolicinteractionists says and this is what seen in the writings of Ismat Chughtai. Socially constructive patterns in relation with women are present in every society and these patterns are believed as a truth and are practiced throughout the world. She further wrote: 


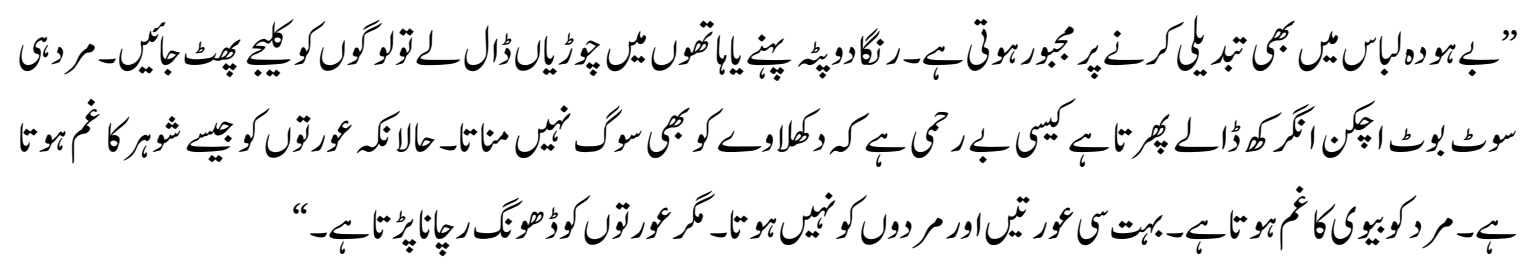

(Chughtai, 2013)

"A widow changes clothes only out of compulsion. Wearing coloured dupatta or bangles in the arms will torment people's hearts like anything. Man dons the same suited booted outfit, or traditional 'angrakh'. How merciless, that he does not show grief even superficially. Although, the way women grieve for their husbands or husbands grieve for their wives. Many women and men do not harbour grief likewise. But women are supposed to dramatize their grief!"

It is a stereotype image that when a husband dies a wife must not live a cheerful life. Especially in Chughtai's time, Indian society does not allow a widow to wear colourful clothes; she had to wear to white colour only. She was not allowed to wear ornaments and make up. Even today a widow is expected to end all her cherish with the life of her husband. On the other hand a wife's death does not make any difference on a widower, although it does, but he does not have to show it. When a widow wanted to live happily the society feels strange about her and if a widower lives with the memories of her wife the world laugh at him. It shows that a woman's departure from this world is sad but a husband's death is supposed to shatter the world of wife.

She further wrote:

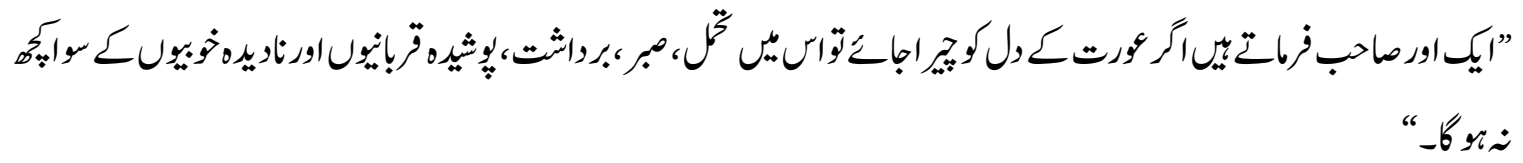

(Chughtai, 2013)

"Another gentleman states that if a woman's heart is pierced, it would only show patience, forbearance, tolerance, untold sacrifices and unseen virtues."

It is just a generalized belief, in fact an impossible standard imposed on women to be followed where society wants a woman to be patient, forbearer, compromising and sacrificing. This generalization has a great impact on women that even mother socializes her girls to be a superficial character. At one point she denied the typecast about mothers. A mother is believed to sacrifice her whole life, career everything for her child. She has 
to bear every agony for her Children. A mother who wants to do something for her does not liked by the society. Chughtai wrote:

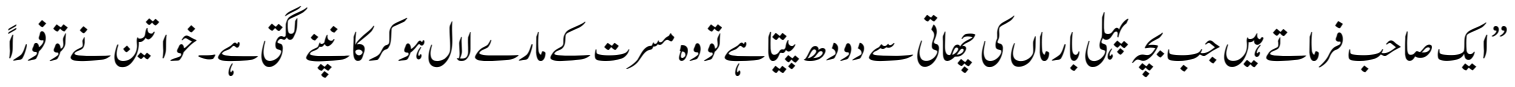

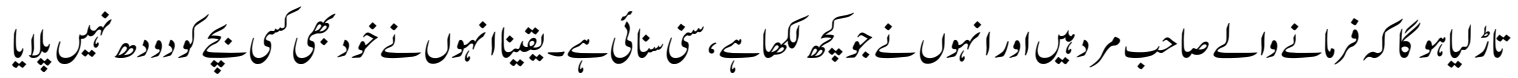

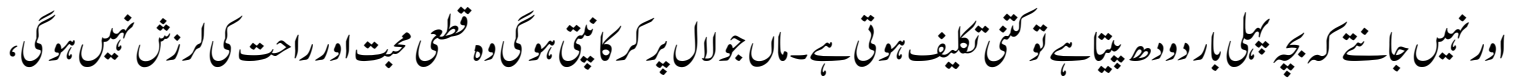

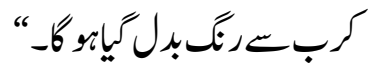

(Chughtai, 2013)

"Another gentleman says that when a mother breastfeeds her child for the first time, she turns red and trembles with joy. Rejecting this argument she says that what this gentleman says is based on hearsay. Certainly he has not breastfed any baby. When a woman breastfeeds her child for the first time, she experiences utmost pain, and the tremors are those of unbearable pain."

It is keenly observed that a mother is perceived to be patient and she has to tolerate each and every pain. If a mother complains about the behaviour of her child and wants to discuss her problems she is told that she has to bear it as she is a mother whose only task is to put up with her throbbing but glorified motherhood.

In her short story, "Baykaar" Ismat portrayed the image of a working woman as perceived by the society. A working woman, in Ismat's time, was thought to be a sex symbol, who at work place seduced her bosses. When Hajira Bi joined a school to support her family, she became talk of the town and her husband Baqar Mian had to face taunts of his friends.

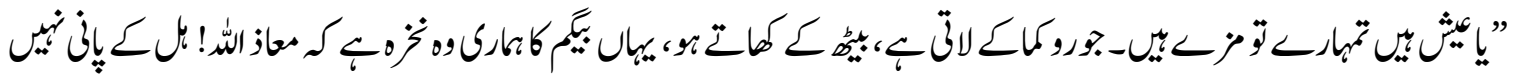

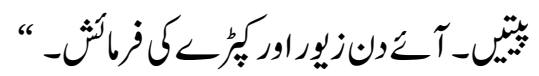

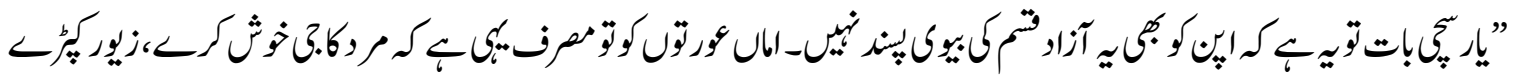

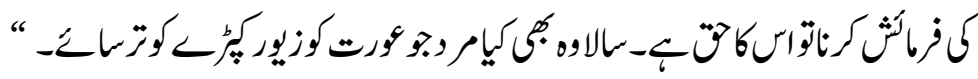

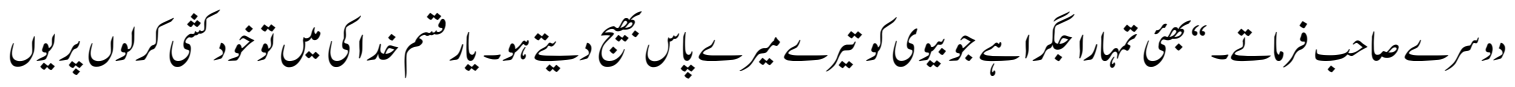

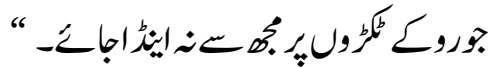




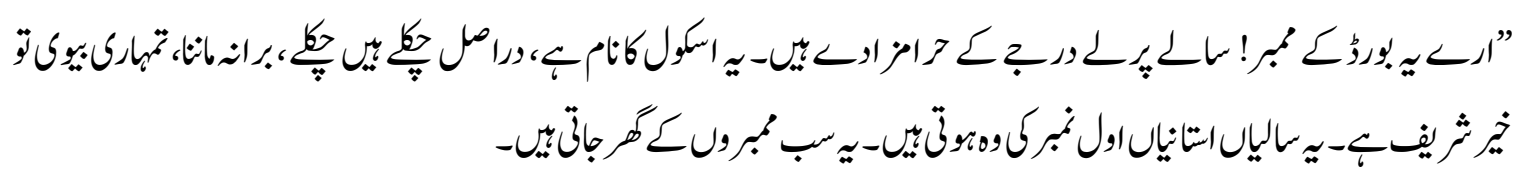

(Abdur-Rehman, 2012)

"Buddy, you are enjoying. You sit in idle dalliance and feed on what your wife earns. God forbid! My wife is so demanding that she would not budge an inch to drink a glass of water. And her never ending demands for clothes and jewellery.

To tell you the truth, I myself do not approve of this liberal kind of wife, Friend! Her only use is to amuse her man's heart. Demanding clothes and jewellery is her right. Woe upon that man who frustrates her woman in providing clothes and jewellery. Another man states, "You certainly have the guts to send your wife here and there. I shall rather commit suicide but will not bear the brunt of feeding on my wife's earning of bread and butter.

' $O$ all these members of board, these are all downright rascals. The school exists in name only, and if you don't mind, your wife is innocent, but all these school teachers are complete sluts. They go to every member's house."

Here it is observed how Chughtai portrayed the image of a working woman in a patriarchal structure. A woman is acceptable even admired, when she demands for clothing and jewellery but a woman who is earning bread for the family is perceived as a prostitute.

\section{Conclusions}

"Chughtai is relevant even today. No study of the Urdu short story, feminism in Urdu literature or Progressive philosophy in Urdu literature can truly be called complete unless her works are taken into account.'(Parekh, 2015)

Ismat Chughtai's writings are mostly analysed psychologically but the present study concludes that Ismat's work is clearly relevant to society, culture and sociology. The subsequent study also concludes that Ismat Chughtai perceives the women of her time as subordinated and ill-treated in eastern as well as in western society. She portrayed that oppressed women in her writings. In "Khareed lo", the character of Cathy experienced the society as a place where a woman had to decorate herself in order to survive. At workplaces, schools, colleges and at home women must make their male counterparts happy. Ismat criticized advertisements for the portrayal of women as a sex symbol. In the story, "Tera Hath", Chughtai presented that in every society a woman is expected to be a subservient, meek and passive. By referencing stories of Mills and 
Boon and Barbara Cortland, she claims that women portray the image of a submissive woman whose only motive of the life is to achieve the love of her hero. As it is shown in the characters of Ghazala, Ammi and Khala Amma, those were born and socialized as one obedient being to men. In "Paisha" Chughtai present a woman in art. A female body is always a centre of attraction for men. In a culture of sub-continent where a woman was a secret object at Chughtai's time, men satisfied their desires through the discussion on nude portraits and sculptures of women. As it is, in her novel, "Dil ki Dunya", the leading female character Qudsia Bano is compelled by society and culture to continue her marriage despite her husband's absence from marriage for ten years. Patriarchal society expects women to carry the burden of relationship and want her to continue a dead marriage by living like a dead body or a widow. Qudsia Bano's rebellion is a message in Ismat's writing that she learned through her experience that a woman must fight against these centuries old rules set by men for their benefit. Qudsia's rebellion is a lesson taught to women to fight against the patriarchal structure, do not accept the unjust behaviour of husband or anyone else, do not accept cruel cultural practices as fate, learn to reacts differently to this situation of informal social control, which is seen in this novel when Qudsia Bano is directed to live simply and was not allowed to decorate herself, a female child is treated as a fragile object, she had to talk and walk with delicacy and she presented this type of society in this novel. In her essay "Aurat", she presented clichés which impersonate women as cringing or submissive. She denied these stereotypes in her essay. It is concluded that Ismat Chugtai wrote of women's social issues a century ago which is now theory and practice of gender sociology in terms of social interaction pattern; her writings are of huge significance in regards to understands culture of Muslim colonial women.

\section{Recommendations}

1. It is suggested that the canvas to see Ismat Chughtai's writings should be broadened.

2. Since her writing are always analyzed psychologically, it is recommended that sociological and philosophical aspects of her writings should be examined.

3. The presence of cultural aspects of British Indian Muslim society especially the colloquial Urdu, the language of native speakers and culture of UP. 


\section{References}

Abdur-Rehman, R. (2012). Afsanay: Ismat Chughtai. Lahore: Book Home

Ahmed, Z. (2009). Pakistani Feminist Fiction and the Empowerment of Women. Pakistaaniyat: A Journal of Pakistan Studies

Chaudhary, F. (2013). Hiding and Seeking Identity: The Female Figure in the Novels of Pakistani Female Writers in English: A Feminist Approach (Doctoral Dissertation) http://eprints.hud.ac.uk/17563/1/fchaudharyfinalthesis.pdf

Chughtai, I. (2013). Kuliyaat-e-Ismat:Ismat Kay Mukammal Novel. Lahore: Muhammad Deen Printers

Chughtai, I. (2013). Ismat Kay 100 Afsanay, Lahore: Muhammad Deen Printers

Chughtai, I. (n.d.). Ismat Ke Shahkar Afsaanay. Lahore: Aftab Press

Crosier, J. (2010).The Creative Soul of Emily Bronte: A Study of the Role of SelfReflective Learning Theory in the Development of a Writing Genius. Forum On Public Policy. http://forumonpublicpolicy.com/spring2010.vol2010/spring2010 archive/crosier.pdf.

Farrukhi, A. The Literary Feminist: A Narrative of Memories of Ismat Chughtai. (2015, August 30) The Dawn, p.07.

Jackson, E. (2010). Feminism and Contemporary Indian Women's Writings. London: Palgrave Mcmillan Publishers.

Khan, H.N. (2008). Treatment of Wife's Body in the Fiction of Indian Sub-Continent Muslim Women Writers. P.hD Dissertation. The University of Southern Mississipi.

Khanna, T. (2014). Gender, Self Representation and Sexualized Spaces: A Reading of IsmatChughta'sLihaaf. Impact: International Journal of Humanaties, Arts and Literature, vol.7:2, pp.49-54.

Macionis, J. (1989). Sociology. New Jersey: Prentice-Hall. Inc. 
Mazzuchelli, P. (2009). The Rebellious Angel. (Master's Dissertation) http://digitalcommons.ric.edu/cgi/viewcontent.cgi?article=1021\&context=etd

Parekh, R. IsmatChughtai: Her life, thought and art. (2015, August 30) The Dawn, p.06.

Pradeep,S.(2013). Ismat Chughtai. http://shanthipradeep.blogspot.com/2013/07/ ismatchughtai.html.

Ritzer, G. (2011). Sociological Theory. New York: McGraw Hills.

Sheriden, M, and Kaivola, K. (n.d.).A Beacon of True Femaleness: A Sociological Analysis of Virginia Woolf"s to the Lighthouse. Inkwell Journal, http://www2.stetson.edu/inkwell/msheridan-paper.pdf

Sabahat Raza is M.Phil Research Student in the Department of Sociology, University of Karachi.

Dr. Naila Usman Siddiqui is an Associate Professor in the Department of Sociology, University of Karachi. 


\section{Glossary}

$\begin{array}{lll}\text { Adb-e-Latif } & : \text { An Urdu literary journal of British India. } \\ \text { Ammi } & : \text { An Urdu word to call mother. } \\ \text { Aurat } & : \text { "Woman" an essay written by Ismat Chughtai. } \\ \text { Baqar Mian } & : \text { A male character from Ismat's story, "Baykar". } \\ \text { Bashariya } & : \text { Name of a female character of Ismat's writings. } \\ \text { Baykaar } & : \text { "Unemployed" is a short story written by Ismat Chughtai. } \\ \text { Bi Amma } & : \text { Mother } \\ \text { Dil Ki Dunya } & : \text { "The Heart Breaks Free" is the novel written by Ismat chughtai. } \\ \text { Gainda } & : \text { A female character of Ismat chughtai's story. } \\ \text { Hajira Bi } & : \text { Name of a female character of Ismat's Chughtai's story, "Baykar". } \\ \text { Hamida } & : \text { A } \\ \text { Kajal } & : \text { A cosmetic which usually puts on in the eyes. } \\ \text { Khala } & : \text { Maternal Aunt } \\ \text { Khala Amma } & : \text { Maternal aunt. } \\ \text { Khareed Lo } & : \text { "Purchase" a short story written by Ismat Chughtai. } \\ \text { Kubra } & : \text { A female character of Ismat Chughtai's story, "The wedding suit". } \\ \text { Lajo } & : \text { Name of a female character of Ismat Chughtai's story. } \\ \text { Lihaaf } & : \text { "The Quilt" a short story written by Ismat Chughtai. } \\ \text { Mirza } & : \text { Name of a male character of Ismat Chughtai's story. } \\ \text { Naat } & : \text { A poetry which tributes Prophet Muhammad specifically. } \\ \text { Nanhi Ki Naani } & : \text { "Tiny's Granny", a short story written by Ismat Chughtai. } \\ \text { Paisha } & : \text { "Profession" is a short story written by Ismat Chughtai. } \\ \text { Qudsia Bano } & : \text { A female character from Ismat's novel Dil Ki Dunya or The Heart } \\ \text { Rahat } & : \text { Breaks Free. } \\ \text { Samina } & : \text { A male character from Ismat chughtai's story, "The Wedding suit". } \\ \text { Shabbir Hasan } & : \text { A male character from Ismat's novel Dil Ki Dunya or The Heart } \\ \text { Shariyat } & : \text { Islamic jurisprudence. } \\ \text { Tera Haath } & : \text { A private sphere in a Muslim household where women were kept } \\ \text { Zenana } & \text { and it had no connection with the outer world. } \\ & \end{array}$

